\title{
Contribution to Cultural Organization, Working Motivation and Job Satisfaction on the Performance of Primary School Teacher
}

\author{
Murtedjo $^{1} \&$ Suharningsih ${ }^{2}$ \\ ${ }^{1}$ Geography education department, faculty of social sciences and Low, State University of Surabaya (UNESA), \\ Indonesia \\ ${ }^{2}$ PPKN department, faculty of social sciences and Low, State University of Surabaya (UNESA), Indonesia \\ Correspondence: Priyono, Post Graduate Management Program, University Bina Darma Palembang, Indonesia. \\ E-mail: priyono.unu_sidoarjo@yahoo.com
}

Received: September 8, 2016

Accepted: September 27, 2016

Online Published: October 7, 2016

doi:10.5430/ijhe.v5n4p86

URL: http://dx.doi.org/10.5430/ijhe.v5n4p86

\begin{abstract}
The purpose of this study are: (1) describes the performance of the teacher, organizational culture, work motivation and job satisfaction; (2) determine whether there is a significant direct relationship between organizational culture, work motivation and job satisfaction on the performance of primary school teachers. Through the study of the structural model, the variables are arranged in the form of a variable-lane diagram to find a model of the relationship between variables. Furthermore, hypothesis testing using Smart PLS Tools. Based on the results of hypothesis testing, factors organizational culture and work motivation is not directly related to the performance of primary school teachers. Job satisfaction factors have a direct relationship and significant the performance of primary school teachers. The results can be used as a basis for the development of teacher performance. For the education department, the results of this study can be used for the development of teacher resources and the quality of learning. For other researchers, the results of this study can be used as a trigger to develop similar research.
\end{abstract}

Keywords: Organizational culture, Work motivation, Job satisfaction, Teacher performance

\section{Introduction}

The era of globalization and reforms to encourage the rise of people's expectations towards the success of national development to make the nation self-sufficient and highly competitive. In the long-term development plan (RPJP) from 2005 to 2015, these expectations as a realization of the vision that has been formulated. The vision outlined that national development to make the people of Indonesia as an independent nation, advanced, just, and prosperous. Realize the vision through the implementation of its programs, national development is realized gradually.

The stages leading independent Indonesian nation and high competitiveness can not be separated from national education program. Therefore, educational programs that can generate resources for development should be scheduled as a priority in the context of national development. Accuracy in the determination of educational programs will have an impact on development outcomes.

In Law No. 12 Year 2007 on the Long Term Development Plan (RPJP) 2005-2025 mentioned that the level of education of the population of Indonesia has increased. The increase was measured by an increase in the literacy rate of the population aged 15 years and over who are not graduated SMP / MTs equivalent to the above, increasing school enrollment for all school-age group. Despite this condition has been achieved is not sufficient in order to global competition, especially in the face of 2020, in which the Indonesian people entering the free market (Ali, 2009). Furthermore, Ali (2009) said that intense competition in the free market must be won by the Indonesian people. This can be achieved if the people of Indonesia have high competitiveness. Winning the competition is key to achieving progress and prosperity of the nation.

Challenges faced in efforts to achieve progress and prosperity of the nation lies in the low human resources in Indonesia, resulting in low productivity of labor and the competitiveness of nations. These things are closely related to education. Therefore, the development in the field of education should be given priority in the national development system. Development of human resources is determined by the educational system and the professional capability of teachers. 
Education is the most effective efforts in overcoming the limitations of academic ability. Through the provision of education in addition be given a range of knowledge, skills, attitudes, also developed various skills needed in everyday life, so that it can participate in national development in accordance with their respective areas of expertise.

Act No. 20 of 2003 on National Education System, has set about basic education. Article 17 paragraph (1) and (2) confirms that basic education is education that underlies secondary education. Shaped basic education elementary school (SD) and Islamic Elementary School (MI) or other equivalent forms, as well as the Junior High School (SMP) and MTs (MTs) or other forms equivalent.

Basic education especially primary school is the basis of the level of schooling and further education level. Collier and Walsh (1971) suggested that primary school is one of the forms and levels of education whose existence is very urgent. Urgency of education is that everyone recognizes that without going through or finish elementary school education or its equivalent, may not be able to follow the further education (Stoops \& Johnson, 1967). Furthermore Stoops \& Johnson (1967) explains that by looking at the importance of the role of the primary school, it is necessary to be prepared as well as possible regarding social institutional and functional academic, especially with regard to the readiness of teacher resources.

The teacher is a person who's most responsible for the success of education. The teacher has the function, role and strategic position in the administration of quality education. Article 32 paragraph (2) of Law Number 20 Year 2003 on National Education System states that teachers are professionals, learning the organization's mission is the establishment in accordance with the principles of professionalism to cater for equal rights for all citizens in obtaining quality education. One measure of professionalism for teachers is the feasibility of carrying out his duties. With the feasibility level, it is assumed that teachers will have high performance (Depdiknas, 2006).

Basically there are various factors that can affect the success of education, such factors: teachers, students, facilities and infrastructure, curriculum and educational environment. From some of these factors, the teacher in teaching and learning in schools occupy a very important position. In some studies found that teachers have an important role in spite of the limited facilities and infrastructure. The study in 16 developing countries, teachers contribute to student achievement by $34 \%$, management contributed $22 \%$, while the influence of infrastructure by $23 \%$. Furthermore, Supriya (in Mahmudi, 2007) in his research found that $76.6 \%$ of student learning outcomes are influenced by the performance of teachers, with details: the ability of teachers to teach at $32.43 \%$, mastery of the subject matter of $32.38 \%$, and the attitudes of teachers towards subjects gave a contribution of $8.60 \%$. From some of the research findings can be said that the performance of teachers affects student achievement. Evidence from the field suggests that performance is affected by many factors, among others: organizational culture, motivation, and job satisfaction.

Addresses the issue of organizational culture is a necessity for an organization because organizational culture is essential for an organization. Organizational culture is a philosophy, ideology, values, assumptions, beliefs, expectations, attitudes and norms that held together and bind in a particular community. Specifically, the organizational culture will be determined by the condition of the working team, the leader, and the character of the organization, as well as administrative processes applies. Organizational culture is important in an institution because it is the habits that occur in the organizational hierarchy representing behavioral norms followed by members of an organization that can make an organization stronger and goals of the organization can be accommodated. To that end, the organizational culture as a concept and as an institution is needed in the organization.

The concept of culture has long been introduced by an expert teacher anthropology, and defines it as knowledge, belief, art, law, morals, customs, and capabilities and habits needed someone as a member of society. Cultures containing patterns, either explicit or implicit, of and for the required behavior and embodied in symbols, the work groups may vary, as objects of human creation. The main core of culture consists of traditional ideas and values that accompany it (Kroeber \& Kluckhon, 1992). Cultural orientation of a community reflects the interaction of a set of characteristics, such as: (1) Studying, cultures treated and realized through study, observation and experience; (2) Sharing, a culture developed through communication between individuals, between groups, and between families; (3) Transgeneration, an accumulation of generation to the next generation and beyond any other generation; (4) The perception of influence, shape the behavior and structure of how people judge the world; (5) Adaptation, cultural change is based on the capacity of individuals to adapt.

Individuals in the community expression character through the values of life and the world around him. These values will otherwise affect individual attitudes concerning forms of behavior that is considered more effective in situations of the organization. From the above mentioned characteristics indicate that organizational culture has the same nature and purpose. Thus, organizational culture can be described as a system of values, norms, way of life, beliefs and attitudes, 
which is owned by members of the organization. All aspects of organizational culture can influence and shape the behavior of its members in carrying out the tasks of the organization.

Strong organizational culture reflected by the employees with a clear understanding of the system of shared meaning held by members, so as to distinguish certain organizations with other organizations. The system of shared meaning is a set of characteristics that are valued by the organization. A set of characteristics, including: (1) innovation and risk-taking; (2) attention to detail; (3) results orientation; (4) aggressiveness; and (5) stability (Robbins, 2001).

The effectiveness of one's work can be driven by one's motivation at work. Motivation or motives, popular in environments demanding life achievement. The working environment is known to work motivation, in the educational environment known as the motivation to learn. Therefore, the use of the term motivation adapted to the actual context as understood by understanding the motivation itself.

In the cognitive sense, motivation is assumed as an individual activity to determine the basic framework of objectives and determination of behavior to achieve the goal. With affective meaning, meaningful motivation basic attitudes and values held by a person or group of persons to act or not to act. Work motivation is the process that determines the intensity of work, the direction of the work and the power of individuals in carrying out the work (Danim, 2004).

Motivation means the power in man that causes the individual to move or work (As'ad, 2003). Furthermore, Mataheru (1988) explains that the motivation comes from the Latin, meaning movere to move or moves. So, motivation is the movement or effort that a person can get the job done with passion. Furthermore, it is said that in fact the motivation is a feeling or a desire for someone who reside and work in certain circumstances to carry out actions that benefit seen from a personal perspective as well as the organization. Petri (1999) and James (1988) defines motivation as complex forces that make someone willing to start and maintain the working conditions within the organization. Furthermore, Petri explains that the motivation contains several elements, such as: (1) concerned with employment, (2) look for the best way to perform, and (3) the satisfaction in doing so.

From some sense it can be found the essential elements contained in the sense of motivation. First, the driving factor or motive generating both internal and external. Second, the goal is to be achieved, and the third, the strategies needed by individuals or groups to achieve that goal. These elements are psychological mechanisms that will be actualized in achieving objectives.

Psychological mechanisms which meant an accumulation of factors that comes from within the individual, such as personality, intelligence, habits, awareness, interest, talent, willpower, spirit, enthusiasm, and so on; while external factors derived from the environment, whether physical environment, social and organizational regulations. These factors interact and actualized by the individual in the form of capacity performance (working performance) or the production capacity that can in quantity and nature variability.

Motivation as the term is often used interchangeably with other terms, such as the need, the drive and destination (goal). In this regard, the motivation for someone to depend on the strength of motivation itself. Motivation cause why someone trying to reach the goal. With the motivation that is what causes a person to behave that can control and maintain the activities and set goals to be pursued someone.

Herpen and Kees (2002) and Kinman \& Russel (2001), the results of the research say that the intrinsic and extrinsic motivation is something that equally affect one's duties. In this regard, Lawler (1973) suggests that cognitive processes in the perception of a model of motivation plays a central role in shaping the relationship between a person's satisfaction and performance.

Basically that someone at work will feel comfortable and have a high fidelity to the organization if the operation of obtaining job satisfaction in accordance with what is desired. Job satisfaction itself actually has any meaning for one worker. There are two words that should be observed in relation to job satisfaction, the satisfaction and work.

Satisfaction is a display feelings experienced by a person, where what was expected to have met or even what passes beyond what is expected. One's work is an attempt to achieve the goal by gaining income or compensation of its contribution to the work place. Vichio (1995) and Gibson, Eranecerich \& Donelly (2000) explains that job satisfaction is the thinking, feeling, and the tendency of a person's actions are the result of their perceptions of the job. Furthermore Kreitner \& Kinicki (2001) explains that job satisfaction is an affective or emotional responses to the various aspects of a person's job. This definition indicates that job satisfaction is not a single concept. Job satisfaction is a manifestation of excitement or emotional statement that a positive result of the assessment of one job or job experiences (Testa, 1999; Locke, 1989). 
Within the meaning of the statement found job satisfaction is a positive emotional state can be unpleasant or resulting from an assessment of the work or the experiences of one's work. It is influenced by several elements of job satisfaction. Herzberg, Mausnen \& Synderman (1959) says that elements of job satisfaction include: (1) relationship with colleagues; (2) relationship with the head of department; (3) ability and efficiency of the department head; (4) hours of work; (5) opportunity to use initiative; (6) promotion prospects; (7) sallary; (8) job security; (9) The actual work undertaken; (10) overall job satisfaction. On the other hand, Robbins (2001) suggests that the factors that drive job satisfaction include: (a) work that is mentally more challenging; (b) appropriate reward; (c) a more supportive working conditions; (d) work colleagues are supportive; (e) the fit between personality and work.

In social reality, job satisfaction is one's attitude toward work and their perceptions of work and interaction both vertically and horizontally. Thus, job satisfaction reflects an attitude, and not the behavior. Therefore, job satisfaction showed no association with performance (Wibowo, 2007).

Performance (performance) means about what to do, how to do and the results achieved from such work. Performance is basically working strived to achieve the performance to produce a specific output within a predetermined time. Performance as the embodiment of the work on the job, activity and behavior within the specified time limit.

Waldinan (1994) explains that the performance is the combined behavior of the achievements of what was expected to be a choice or part of the terms of an existing task on each individual in the organization. Performance can also be defined as the result of the quality and quantity of work that can be achieved by a person carrying out the duties of employees in accordance with the responsibilities given to him. Meanwhile, Armstrong \& Anggela (1998) interpret the performance of the broader sense, not only regarding work, but also how the work process directly. The performance is about doing the job and how the results achieved from the work, which has a strong relationship with the organization's strategic objectives, customer satisfaction and economic contribution.

From some notion of performance as mentioned above it can be concluded that the performance is in principle a multidimensional construct, includes many factors that can influence it, namely (1) Personal factors include knowledge, skills, confidence, motivation, commitment of every individual; (2) factors of leadership, the quality of giving impetus, encouragement, guidance and support provided by the manager and team leader; (3) Factor team, the quality of the support and encouragement given by teammates, trust in the team, the cohesiveness and the closeness of the team; (4) Factor system, including working system, working facilities, the infrastructure provided by the organization, organizational processes and work culture in the organization; and (5) contextual factors, pressures and changes in the external environment and internal (Mahmudi, 2007).

In the management of modern management, including performance management education is strongly influenced by morale, climate conducive communication between leaders and subordinates in relation to performance. The essence of the performance communication, among others: (1) morale; (2) the position in the work; (3) opportunity in employment; (4) trust. In a favorable opportunity that requires an assessment of performance through essential that the effectiveness and efficiency of performance can be known.

In the traditional performance appraisal system, performance is only associated with the personal factors. However, in reality the performance is often caused by factors beyond personal factors, such as leadership, team and others. In this regard, Campbell (1990) explains that there are many functional relationship between performance and performance attributes, such factors: knowledge, skills, motivation. In building an effective performance and build personal compliance in work organization, these factors are standard operating procedure that must be followed in order to build a culture of work and an understanding of the working culture itself. This understanding will give birth to motivation and job satisfaction.

\section{Research Methods}

This research is a survey research with the hypothesis, because researchers faced a sizeable number of respondents. To test the hypothesis necessary research instruments capable of generating the data interval. In the context of data and the number of respondents that used research with a quantitative approach (Fornell \& Bookstain, 1982). The purpose of this study was to analyze the relationship between the variables of organizational culture, work motivation and job satisfaction with the performance of teachers. For this purpose, used path analysis, because these analytical techniques can explain the relationship between variables either directly or indirectly (Solimun, 2002). On the basis of the relevance of the approach, the type of research and analysis techniques used and the objectives are achieved, then developed a research design that can be seen in Figure 1: 


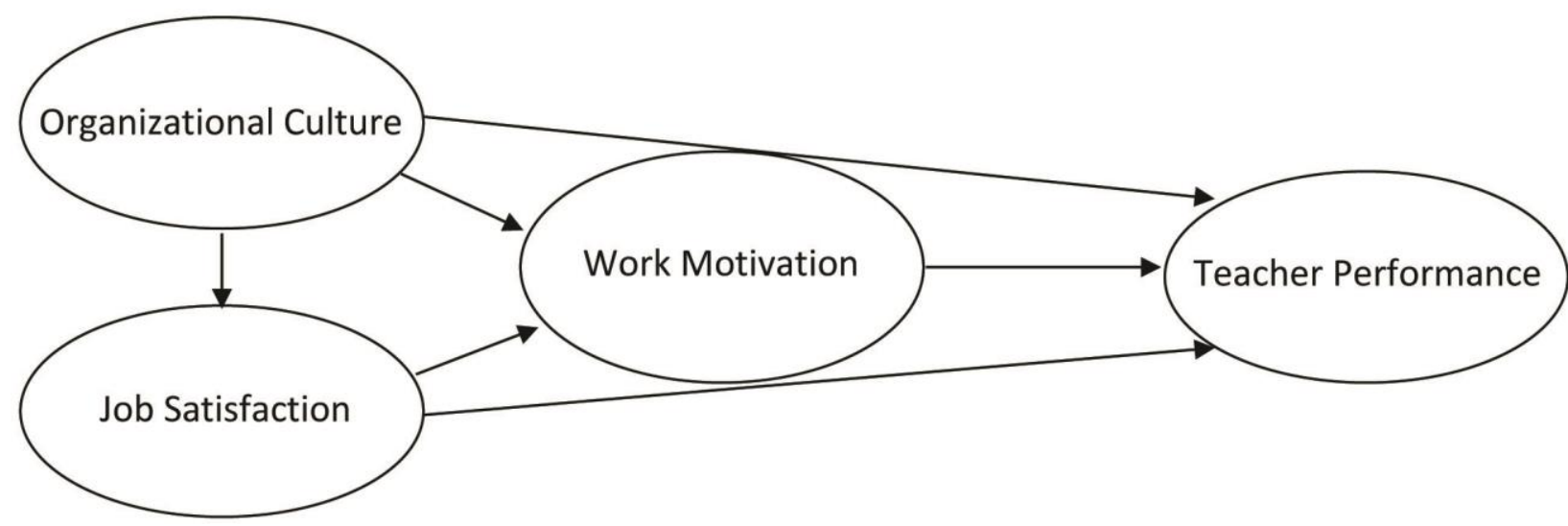

Figure 1. Conceptual Model Design Research

Through the study population for the purpose of reaching generalization region consisting of objects or subjects of research that have a certain quantity and characteristics defined by the researchers to be learned and conclusions drawn possibility (Sugiyono, 2007). The population in this study are all primary school teachers were civil servants in the city of Surabaya, amounting to 7610 people. Because survey research, the implementation uses a sample.

Through the study population for the purpose of reaching generalization region consisting of objects or subjects of research that have a certain quantity and characteristics defined by the researchers to be learned and conclusions drawn possibility (Sugiyono, 2007). The population in this study are all state elementary school teachers were civil servants in the city of Surabaya, amounting to 7610 people. Because survey research, the implementation uses a sample.

Samples are part of the overall number and characteristics of the study population (Sugiyono, 2008; Moore, 1983). The research sample must be truly representative, should therefore be chosen from all the elementary unit so as to have the same opportunities, taking into account the following factors: (1) the degree of uniformity (degree of homogeneity), the more homogeneous, then the smaller the population is taken. If the population was uniform (completely homogenous), then an elementary unit alone is sufficiently representative to be investigated; (2) precision desired by the researcher. The higher the expected precision, the sample size needed; (3) the analysis plan. In one study design sometimes has insufficient sample size in accordance with the desired precision, but when linked with the needs analysis, the sample size is not sufficient; and (4) labor, cost and time, if you want a high-precision, then the sample size should be large. This will lead to the provision of energy, cost, and time required for completion of the study (Singarimbun \& Effendi, 1989). Through satisfied proportional random sampling and assisted by the formula Warwisk \& Liningger (in Sugiyono, 2008), then the number of 174 samples were obtained from a population of 7610 people.

\section{PLS Steps are as follows:}

\subsection{Designing Model or Inner Structural Model}

Inner model is a model that specifies the relationship between latent variables based on the substance of the theory (Ghozali, 2008). Inner model can be seen in Figure 2.

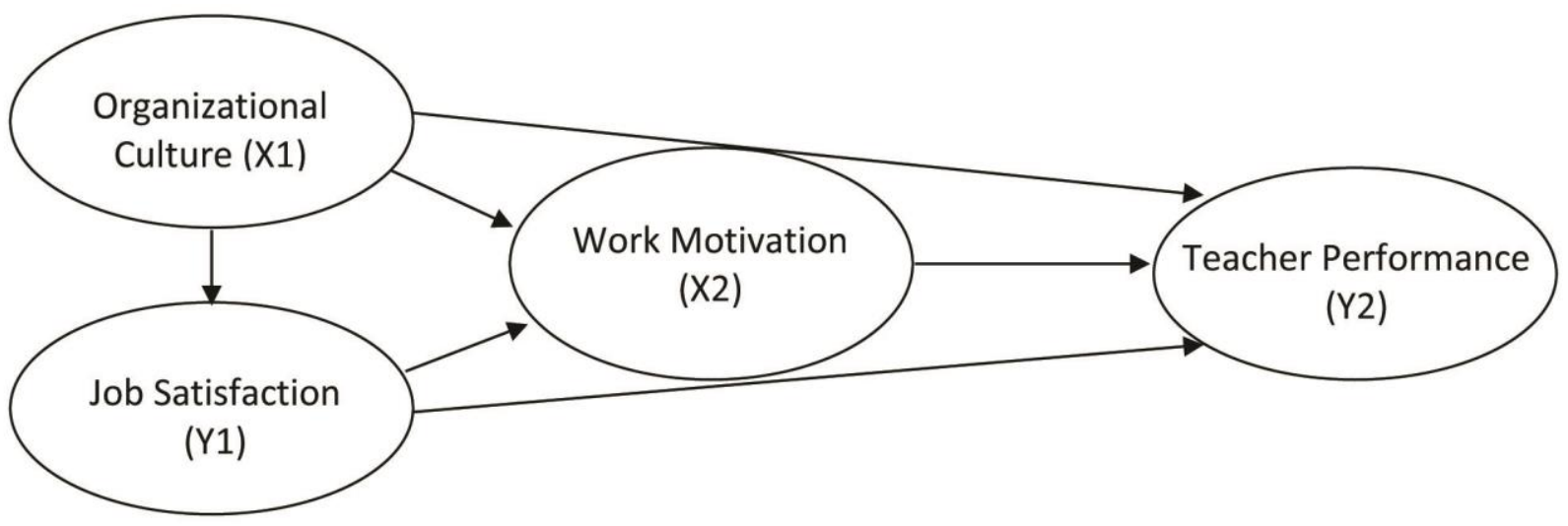

Figure 2. Diagram Line Between Variables 


\subsection{Designing Measurement Model or Outer Model}

At PLS draft measurement models (outer model) becomes very important, because the measurement model is a model that specifies the relationship between latent variables with the indicators (Ghozali, 2008). The design of the measurement model that describes the relationship between latent variables with the indicators can be seen in Figure 3.
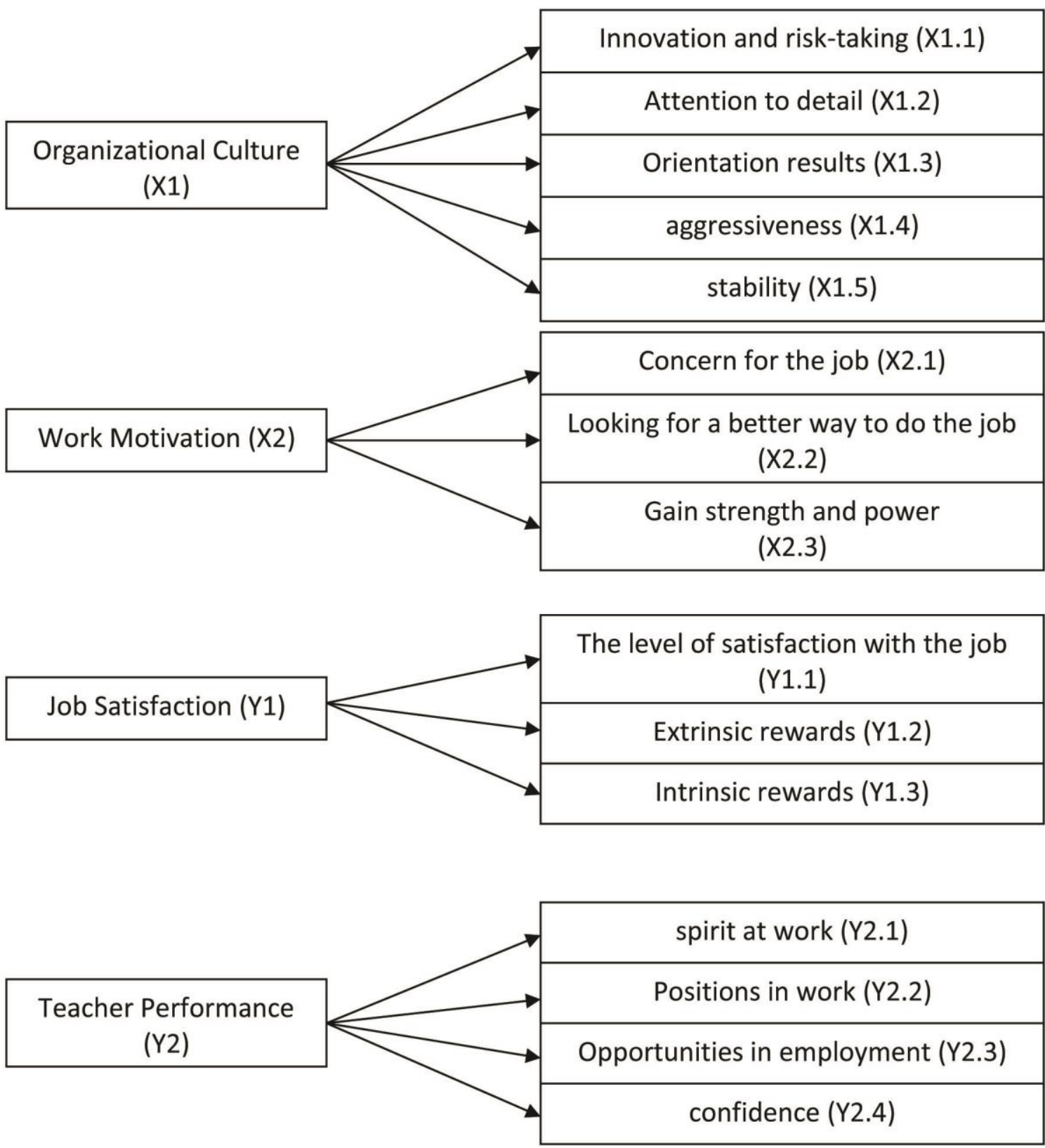

Figure 3. Design Outer Model

\subsection{Arrange or Construct Diagram Path Diagrams Every Variable Path}

This diagram is useful to show the path of a causal relationship between exogenous and endogenous. Causal relationships between variables can be seen in Figure 4.

Constructs were built as in the diagram above path can be divided into two groups of exogenous variables, ie organizational culture (X1), as well as variable indogen which includes work motivation (X2), job satisfaction (Y1) and teacher performance (Y2). 


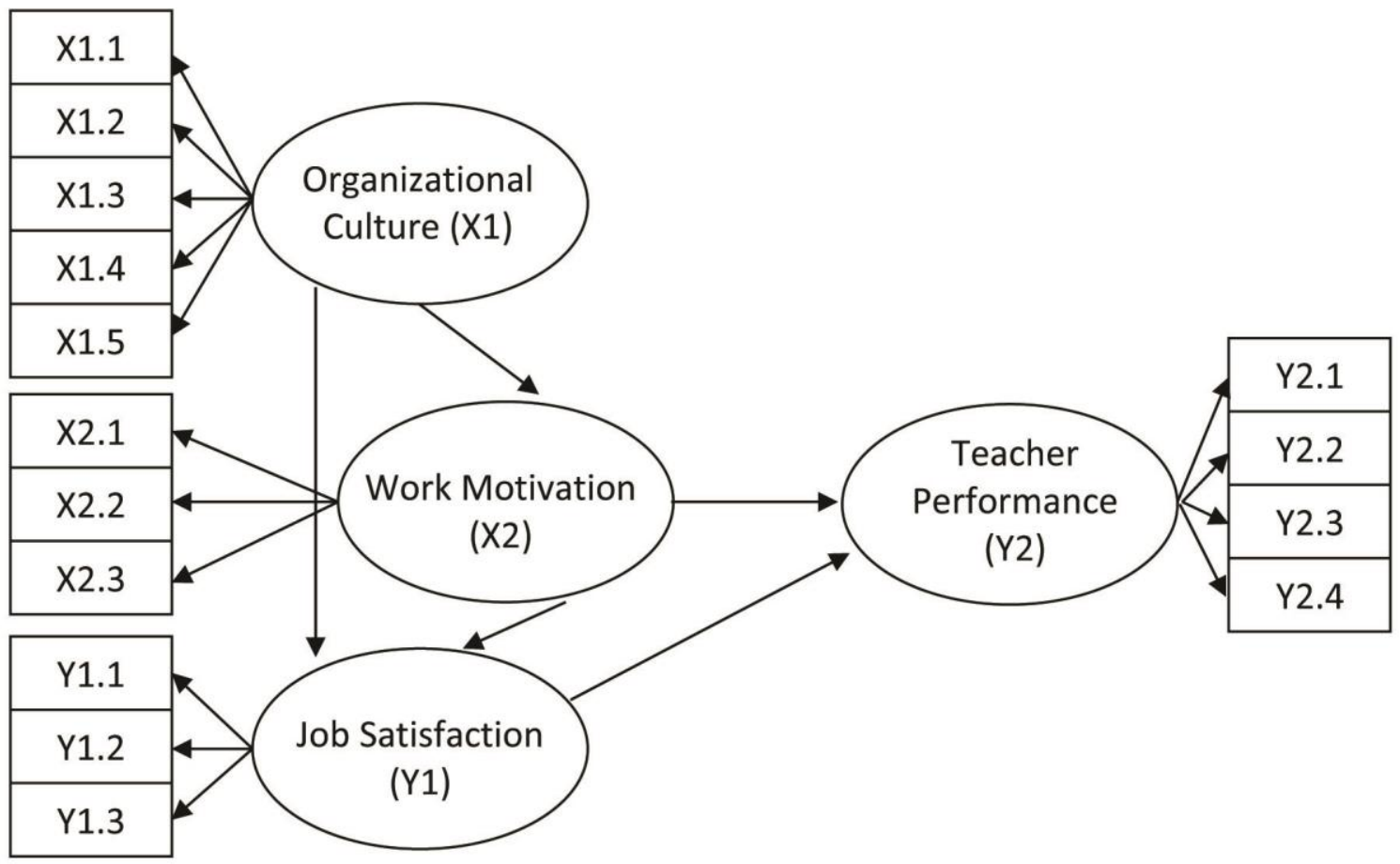

Figure 4. Diagram for PLS Path

\subsection{Hypothesis Testing}

Statistical hypothesis testing was done by t-test. When the p-values obtained value $<0.05$ (5\% alpha), it was concluded significant and vice versa. When the results of testing on the outer significant models, it indicates that the existing indicators are thought to be used as a measuring instrument latent variables. When the results of testing on the model inner significantly, it means there is a significant effect of latent variables to other latent variables.

\section{Results and Discussion}

Based on the categorization of teacher performance variables can be seen that the performance of the State Primary School teachers mostly in middle category (35.6\%). This category relates to the level of teacher performance, still contain the problem, because the teacher's performance is an indicator of the level of achievement that can be achieved and reflects the success in learning. With these categories, then the performance of the State Primary School teacher in the learning still needs to be improved, because the role of the teacher in learning is very central and determining educational success (Suharningsih, 2009). Powered research Kotter and Heskett (1997) that the performance can be influenced by the culture of the organization. Strauss and Syales research results quoted by Handoko (2001) stated that the performance of its members and in turn, will increase the culture of organizations.

Organizational culture as a system of shared meaning held by teachers of primary schools most (42.5\%), is in good enough category, the rest are in the very good category (17.2\%), both categories cover $36.2 \%$, unfavorable category of $1.1 \%$ and $2.9 \%$ are not good. Furthermore, it can be explained that organizational culture is often paired with the corporate culture. Corporate culture characteristics such as innovation, the courage to take risks, when used as the basis for any conduct of its work, will make the values contained in the innovation and courage to take risks such as personality organization (Djokosantoso, 2003).

In the context of this study are implemented organizational culture in the learning process. At each start the learning activities, teachers prepare lesson plans, implementing the lesson plans and ending with the assessment of learning activities.

As noted by Banghart \& Trull (in Majid 2008), planning is the beginning of all rational process and contains optimism based on trust, that will be able to overcome the various problems. Planning is the systematic process of making decisions about actions to be taken in the future. While implementing learning plans, is defined as the process undertaken by teachers in guiding, helping and directing learners to have a learning experience, whether cognitive, affective and psychomotor. Another important component is the evaluation or assessment. Evaluation with 
all its meaning is a systematic process, from data collection, analysis and interpretation of data and assessment information, to determine the extent to which learners achieve the goals that have been set (Guba \& Lincoln, 1981).

From the results of the study showed that the correlation coefficient in the path of the construct of organizational culture with the construct of teacher performance, there is no significant direct relationship with job satisfaction. School organizational culture which is a reflection of the culture of the majority of teachers are in the category quite well. So nothing to do with the organizational culture of performance. The better the organizational culture of the higher performance of a person (Kotter \& Heskeet (1997). The higher the person's performance is getting to meet the needs that motivate a person working in improving the quality of work to get to a level of satisfaction.

Wexley \& Yukl statement, motivation, quoted by As'ad (2003), states that motivation is a background process that individuals behave in order to achieve objectives (motivation is the process by the which behavior is energized and directed). Motivation someone will look at the behavior of workers who are directed to the achievement of the target to meet the integrity to achieve satisfaction.

The relationship between the constructs work motivation and job satisfaction shown by the path coefficient of both constructs in the amount of 0.268018 (coefficient is positive), the value of t-statistic of 2.547287 . With a significance level of 5\% (two-tailed), obtained t-table is 1.974. It shows that the t-statistic $>\mathrm{t}$-table, meaning that a significant correlation coefficient. The study results support the research Wright (2001) with the title of public sector work motivation: A review of current literature and a revised conceptual model. Wright (2001) concluded that work motivation influence behavior, while encouraging motivation and behavior of public sector performance. So work motivation variable interconnected with job satisfaction and jointly affect work productivity.

Based on the categorization of job satisfaction variables (Y1), it can be seen that the level of job satisfaction most of the teachers state elementary school in middle category with a frequency of $36.8 \%$., Thus according to Strauss \& Syales quoted Handoko (1992), job satisfaction is important for self-actualization. In organizational life, every individual who can actualize themselves, felt participate in the achievement of organizational goals, so feel a greater job satisfaction. There is some suggestion that there is a positive relationship between job satisfaction and employee performance. Research cavity (2001) with the title: Human Resources Practices, Organizational Climate and Employee statisfaction concluded that (a) human resources have influence $69 \%$ of organizational culture, (b) organizational culture has an impact of $90 \%$ on employee job satisfaction.

From the results of quantitative analysis, it is known that the path coefficient of job satisfaction construct to construct a teacher's performance amounted to 0.344209 and the t-statistic of 3.2950032. With a significance level of 5\% (two-tailed), obtained t-table is 1.974 . This shows that the $\mathrm{t}$-statistic $>\mathrm{t}$-table, this means that the $\mathrm{t}$-statistic is significant. Decisions can be taken that path coefficients showed significant correlation between job satisfaction construct with teacher performance and claimed there was a significant direct relationship between job satisfaction and performance of teachers.

Some views relating to the relationship between job satisfaction and performance, as proposed by Gordon (1989), that when performance is positively related to satisfaction, it appears the three views (1) the satisfaction of causing the performance, (2) the performance of causes of satisfaction and (3) awards, disturbing no inherent relationship. Organ and Bateman (1986), stating that the performance includes various behaviors about what to do, how to do it and the results of such work. Such behavior is more common to workers who are satisfied. So the job satisfaction has a significant connection with the performance of teachers

From the description it can be seen that, directly or indirectly, no significant relationship between organizational culture, motivation and job satisfaction with the performance of teachers. Proposition between these variables confirms that teacher performance can go up or down in relation to the increase or decrease in organizational culture, motivation and job satisfaction.

\section{Conclusions and Suggestions}

From the description above, it can be deduced as follows:

1) Organizational Culture in the State Elementary School in general is good enough. This illustrates that the work culture of teachers have met the service standards of quality in teaching and learning. Quality services performed by teachers State Primary School, that at each implementation of the process of teaching and learning, always use the stages of planning, implementation planning and assessment. There is no significant direct relationship between organizational culture and performance of teachers, through motivation and job satisfaction. The findings of this study explains that motivation and job satisfaction have a role in improving the performance of teachers. For that, the 
better the culture of the organization, supported by improvements in the motivation and job satisfaction will be able to improve the performance of teachers.

2) Motivation state elementary school teacher working mostly in middle category, meaning that urge teachers to take action to achieve the goals still need to be improved. There is no significant direct relationship between work motivation with teacher performance through job satisfaction. The findings in this study explains that job satisfaction has a role in improving the performance of teachers. The better motivation is supported by the higher job satisfaction can improve the performance of state elementary school teacher.

3) Job satisfaction Public Elementary School teacher in middle category. Teacher job satisfaction, especially primary school teachers, should be properly maintained, because satisfaction is related to a person's emotions are pleasant or unpleasant. This will be able to influence in providing services to the students. The implications of this condition appear on socioemotional climate class where the teacher was.

\section{References}

Ali, M. (2009). Education for National Development. Jakarta, PT. Imperial Bhakti Utama.

Armstrong, M. \& Anggela, B. (1998). Performance Management. London: Institute of Personal and Development.

As'ad, M. (2003). Psykologi Islami, Human Resources Series. Yogyakarta, Liberty.

Campbell, D. (1990). The Force Prejudice, The Gurdian, 31 October.

Collier, C. C. \& Walsh, W. J. (1971). Teaching in the Modern Elementary School. New York: The Macmillan Company.

Danim, S. (2004). Leadership \& Motivation Efectifitas Group. Jakarta, Rineka Reserved.

MONE. (2006). The Ministry of National Education Strategic Plan 2005-2025. Jakarta, Research.

Djokosantoso, M. (2003). Corporate Culture and Corporate Excellence. Jakarta, Alex Media kompetindo.

Fornell, C. \& Bookstain, F. (1982). Two Eqquation Structural Models: LISREL and PLS Applied to Consumer Exit Voice Theory. Journal of Marketing Research, 19, 440-452. http://dx.doi.org/10.2307/3151718

Handoko, T. H. (2001). Human Management Personnel and Resources. Yogyakarta, BPFE, Press.

Ghozali, I. (2008). Model Structural Equation Models and Applications Program Partial Least Square (PLS). Edition III, Publisher Agency Diponegoro University, Semarang.

Gibson, J.L., Evanecevich, J.M., \& Donelly, J.H., Jr. (2000). Organization, Boston, McGraw-Hill Book, Companies, Inc.

Gordon, G. G. \& Ditomaso, N. (1992). Predicting Corporate Performance From Organizational Culture. Journal of Management Study, November 1992, 793-98. http://dx.doi.org/10.1111/j.1467-6486.1992.tb00689.x

Guba, E.G. \& Lincoln, Y.S. (1981). Effective Evaluation; Improving the usefullness of Efaluation Results Trought Responsive and Naturalistic Approaches. San Francisco; Jossey-Bass publishes.

Herpen, M., Praag. M., \& Kees, C. (2002). The Effectif Performance Measurement and Compensation on Motivation and Empirical Study. Conference of The Performance Measurement Association in Boston, pp. 1-34.

Herzberg, F.B., Mausner, \& Synderman, B. (1959). The Motivation to Work. New York: John Wiley and Sons.

James, L. (1988). Understanding Employee Motivation: N / A. June, 36.

Kinman, G. Russell, K. (2001). The Role of Motivation to Learn in Management Education. Journal of Workplace Learning, 3(4), 132-149. http://dx.doi.org/10.1108/13665620110391088

Kotter, J. P. \& Heskett, J. L. (1997). Corporate Culture and Performance. PT. Prehalindo, Simon and Sheester Pte. Ltd.

Kreitner, R. \& Kinicki, A. (1995). Organization Behavior, Third Edition, Printed in the United State of America: Richard D. Irwin Inc.

Kroeber, A. L., \& Klukhon. (1992). Culture Review of Concept and Definition, Paper Peabody Museum, Cambridge, Mass: Harvard University.

Lawler, E. E. III. (1973). Motivation in Work Organization (Monterey, Calif: Books / Cole). 
Locke, E. A. (1989). The Nature and Causes of Job Satisfaction in Dunnette, M. D. (Ed), Hand Book of Industrial Psychology, New York: John Wiley \& Sons.

Mataheru, F. (1988). Work Motivation. Papers be delivered On Teachers' Training College Lecturer Upgrading Malang. Malang, without date.

Mahmudi. (2007). Public Sector Performance Management. Yogyakarta, College of Management Sciences, YKPN.

Majid, A. (2008). Lesson Planning. Bandung, PT. Teens Rodakarya.

Moore, G. W. (1983). Development and Evaluating Educational Research. Toronto, Little Brown \& Company (Canada) Limited.

Organ, D. W. \& Bateman, T. S. (1986). Organization Behavior: An Applied Approach Psychological (Plano Tex: the Business Publication).

Petri, H. (1999). Motivation Theory and Research. Belmont Calif, Wards Warth.

Robbins, S. P. (2001). Organization Behavior. Upper Saddle River, New Jersey Prentice-Hall Inc.

Cavity, K. L. (2001). Prantices Human Resources, Organization Climate and Employee Satisfaction. Academy of Management Review, July, 619-644. External Control of Reinforcment. Psychological Monographs, 1(609), 80.

Singarimbun, M. \& Effendi, S. (1987). Survey Research Methods. Jakarta, LP3ES.

Solimun. (2002). Structural Equation Modelling (SEM), LISREL and AMOS. Malang State University.

Stoops, M. \& Johnson, R. E. (1967). Elementary Schools Administration. New York: McGraw Hill Book Company.

Sugiyono. (2007). Quantitative Research Methods, Qualitative and R \& D Bandung, Alphabeta.

Sugiyono. (2008). Methods of Research Administration. Bandung Alphabeta.

Suharningsih. (2009). Basic School Performance Management in Malang (Multi-Site Study On three Elementary School), University of Malang country, MSc, unpublished dissertation.

Testa, M. R. (1999). Satisfaction with Organization Vision, Job Satisfaction and Service Effort: An Empirical Investigation. Leadership \& Organization Development Journal, 20(3), 154-161. http://dx.doi.org/10.1108/01437739910268424

Vichio, R. P. (1995). Organization Behavior. Florida, The Dryden Press.

Waldman, D. A. (1994). The Contribution of Total Anality Management to a Theory of Work Performance. Academy of Management Review, 19(3), 210-536.

Wibowo. (2007). Performance Management. Jakarta, PT. King Grasindo Persada.

Wright, B. E. (1989). Public Sector Work motivation: Review of Current Literature and Reversed Concional Model. Journal of Public Administration Research and Theory, 11(4), 3369-3830. 